\title{
HOST/PATHOGEN INTERACTIONS BETWEEN SCOTS PINE SEEDLINGS (PINUS SYLVESTRIS L.) AND THE P-STRAINS OF HETEROBASIDION ANNOSUM (FR.) BREF. IN PURE CULTURE
}

\author{
ANTONI WERNER ${ }^{1}$, KRYSTYNA IDZIKOWSKA ${ }^{2}$ \\ 'Department of Phytopathology, Institute of Dendrology, Polish Academy of Sciences \\ Parkowa 5, 62-035 Kórnik, Poland \\ 2Laboratory of Electron Microscopy, Faculty of Biology, Adam Mickiewicz University \\ Grunwaldzka 6, 60-780 Poznań, Poland
}

(Received: March 17, 2000. Accepted: December 6, 2000)

\begin{abstract}
Pinus sylvestris L. seedlings representing half-sib families of several trees of known resistance in field conditions were inoculated with three strains of Heterobasidion annosum (Fr.) Bref. representing the P intersterility group. Standardized inoculation procedure and uniform in vitro conditions allowed for evaluation of the genetically controlled host/pathogen interactions. Early and advanced stages of infection after prolonged exposure to the fungus were studied with the help of light and transmission electron microscopy. Abundance of osmiophilic material in vacuoles, necrotic reaction of cortical cells and secondary thickenings of cell walls in root regions in proximity to external mycelium were responsible for transient stagnation of pathogen spread in the cortex of resistant seedlings. Immobilized and degenerating hyphae inside vacuolar deposits in cortical cells of short roots of resistant plants are indicative of elevated toxicity of the protective materials at the initial stage of infection. Structural changes of vacuolar deposits and their subsequent disappearance, which coincided with heavy colonization of cortical cells of moderately susceptible seedlings, preceded hyphal penetration into the stele within 2-6-months after inoculation. Despite severe damage to root caps, there was no further spread of the fungus into meristems of growing roots and short dormant roots.

In susceptible seedlings, lack of a hypersensitive reaction and apparently low levels of osmiophilic material resulted in quick colonization of cortical cells, breakdown of endodermis and root abortion after entering the stele.
\end{abstract}

KEY WORDS: Pinus sylvestris, Heterobasidion annosum, in vitro, infection, resistance, light microscopy, TEM.

\section{INTRODUCTION}

Heterobasidion annosum (Fr.) Bref., due to its adaptation to living inside standing trees and ability to cause decay of heartwood, is known as a dangerous wood destroyer.

Previous studies on advanced and initial stages of infection in stems and roots of conifers conducted by Shain $(1967,1971)$, Shain and Hillis (1971), Tippett and Shigo (1980, 1981), Johansson and Stenlid (1985), Stenlid and Johansson (1987), provided information on structural and biochemical responses of living sapwood of old spruces involved in host resistance. Results of the recent studies on infection of young nonsuberized and suberized roots of Norway spruce described by Asiegbu et al. (1993, 1994, 1995); Heneen et al. (1994a, 1994b) indicate that seedlings of conifers are favourable to study host/pathogen interactions and host resistance.

Pinus sylvestris L. seedlings can become infected by $H$. annosum very soon after outplanting. Although root injury and environmental stresses predispose thin roots to pathogenic infection, it may be assumed that variation in seedling mortality is partly due to their resistance. A severe Heterobasidion root rot attack leads to gap formation and the emergence of more tolerant indi- viduals in disease centers. Though the supposition that the surviving trees are less susceptible to the pathogen was not verified thoroughly, it yielded several comprehensive studies on the genetic variation in the resistance to $H$. annosum (reviewed in Delatour 1982; Johansson and Unestam 1982; Dimitri 1994). Since most studies have concentrated on changes accompanied with heartrot formation in order to find additional and useful correlations for future breeding programmes, they have provided insufficient information on differences in defence reactions of living tissues.

The use of seedlings to test host resistance and fungus aggressiveness and/or pathogenicity seems to be an alternative to longterm infection experiments on mature trees. The survival of half-sib families of several $P$. sylvestris individuals showing different tolerance to $H$. annosum under forest conditions varied significantly after inoculation with the pathogen at the seedling stage (Werner 1987, 1991a, 1991b).

In search-of inherited resistance a study was initiated on infection process in roots of $P$. sylvestris seedlings, particularly on structural responses of cortical cells to penetration and colonization by the fungus. 
The purpose of this study was to document the events of mutual interactions during the initial and advanced stages of infection of pine seedlings inoculated under standardized axenic in vitro conditions and to evaluate the differences in the host defence reactions among progenies of $P$. sylvestris after prolonged exposure to three strains of $H$. annosum from the $\mathrm{P}$ group.

\section{MATERIALS AND METHODS}

\section{Plant material}

The plant material consisted of Pinus sylvestris seedlings representing half-sib families of nine trees selected in old disease centers in two localities in Poland (Werner 1991a). A total of four trees (two diseased and two healthy) were selected at forest stand near Wronki (latitude $52^{\circ} 44^{\prime} \mathrm{N}$ longitude $16^{\circ} 16^{\prime} \mathrm{E}$ ) and five trees (two diseased and three healthy) were chosen at forest stand near Klęka (latitude 52 $09^{\prime} \mathrm{N}$ longitude $17^{\circ} 24^{\prime} \mathrm{E}$ ).

Three strains of $H$. annosum were selected for the study. The fungi were isolated from roots of diseased pines in three forest stands (Wronki, Klęka and Pniewy) in Poland heavily injured by $H$. annosum and identified on the basis of Spiniger meineckellus (Olson) Stalpers conidial stage after incubation for two weeks on malt-agar at $21^{\circ} \mathrm{C}$. The isolates were assigned to intersterility group $\mathrm{P}$ based on their ability to heterokaryotize homokaryotic tester strains of the P-Is group (Korhonen 1978). Two strains ( $\mathrm{Ha} \mathrm{W} / \mathrm{p}$ and $\mathrm{Ha} \mathrm{K} / \mathrm{p}$ ) were more aggressive, and killed seedlings of the studied pine progenies approximately in 74.45 and $62.25 \%$, whereas a strain $\mathrm{Ha} \mathrm{P} / \mathrm{p}$ only in $33.40 \%$ (Werner 1987).

\section{Growth conditions and inoculation procedures}

Pine seeds were soaked in water, sterilized superficially with $2 \% \mathrm{HgCl}_{2}$ for $4 \mathrm{~min}$ and washed three times (15 min each) in sterile distilled water. Seeds were germinated on $0.6 \%$ agar $(\mathrm{w} / \mathrm{v})$ medium, in the dark at $24^{\circ} \mathrm{C}$. Subsequently, they were aseptically transferred to $300 \times 30 \mathrm{~mm}$ test tubes containing 100 $\mathrm{mL}$ of agar medium (Pachlewska 1968). The seedlings were incubated in a growth room under fluorescent tubes (Osram L36/W77 Flora) $\left(100 \mu \mathrm{Em}^{-2} \mathrm{~s}^{-1}\right)$ light 18 hours a day, $80 \% \mathrm{RH}$ at $24: 20^{\circ} \mathrm{C}$ day:night temperatures. After one month an inoculum disc ( $5 \mathrm{~mm}$ in diameter) of a two-week-old mycelial mat of $H$. annosum was placed on the agar close to the seedling. Control material consisted of noninoculated seedlings.

The degree of host resistance was evaluated by the appearance of disease symptoms and the ability of plants to survive in dual culture for 15 months, as described earlier (Werner 1987, 1991a). Three seedling mortality classes were used to define resistance: (1) seedlings dying during the first month after inoculation were regarded as very susceptible, (2) seedlings surviving till 6 months after inoculation represented a moderately susceptible group; and (3) seedlings surviving till the 15 th month were regarded as resistant.

The seedlings from each progeny were classified to the above three classes.

The external morphology of root systems and the extent of covering of roots by mycelium were examined and photographed directly through the glass of tubes with a Zeiss 30-G711 photostereomicroscope at intervals of 1-2 weeks after inoculation.

\section{Light microscopy $(L M)$}

Roots of 54 plants at various stages of infection and representing three seedling mortality groups of each progeny were examined. Roots of noninoculated (control) seedlings were collected at the same time. Pieces of roots $(3-5 \mathrm{~mm})$ were fixed in FAA for $4 \mathrm{~h}$. Dehydration of roots in an ascending ethyl alcohol-tertiary butyl alcohol (TBA) series was followed by embedding in paraffin (Jensen 1962). The specimens were sectioned with an Autocut 2040 Reichert-Jung rotary microtome. Serial transverse and longitudinal sections 8-10 $\mu \mathrm{m}$ thick were stained by the Conant's quadruple stain method (Johansen 1940).

The colonization of root tissues by the fungus was visualized by staining the sections according to the method of Mallory (Bagiński 1969). Phenolic substances were detected by staining with $1 \%$ solution of toluidine blue $\mathrm{O}$ in acetate buffer, $\mathrm{pH} 4.0$ (Feder and O'Brien 1968). Tanniferous material was stained by treatment of fresh sections with $1 \%$ solution of ferric chloride in $0.1 \mathrm{~N} \mathrm{HCl}$ (Jensen 1962). To detect lignin, the Wiesner reaction (phloroglucinol-HCl) was used (Jensen 1962). Suberin was localized using Sudan B in 70\% ethanol (O'Brien and McCully 1981) or using Sudan IV (Jensen 1962).

In addition to this routine, each region of the root system studied in TEM was correlated with observations of adjacent sections or sections taken from similar parts of roots in light microscopy.

This material was fixed by the same procedure as for TEM. Thicker sections $(1.0-1.5 \mu \mathrm{m})$ were cut with diamond knives and stained with $0.05 \%$ toluidine blue $\mathrm{O}$ in $1 \%$ sodium borate.

\section{Preparation of roots for transmission electron microscopy (TEM)}

Roots covered by mycelium were excised from seedlings each week at the beginning of the experiment for 2 months, and then each month thereafter. Apical, subapical and proximal parts of roots at different developmental stages were selected. Irrespective of this routine, twenty seven dying seedlings representing very susceptible, moderately susceptible and looking-healthy, 8-10month-old resistant plants of each progeny were selected. Uninoculated seedlings of the same age and representing all the studied half-sib families served as a control. Primary roots, and first and second order laterals were cut into 1-2 mm pieces, fixed in $4 \%$ glutaraldehyde in $0.05 \mathrm{M}$ cacodylate buffer at $\mathrm{pH} 7.2$ for $24 \mathrm{~h}$ at $4^{\circ} \mathrm{C}$ and rinsed 3 times for $15 \mathrm{~min}$ each in the same buffer. Subsequently, they were postfixed in $2 \% \mathrm{OsO}_{4}$ in $0.1 \mathrm{M}$ cacodylate buffer for $2 \mathrm{~h}$ at $4^{\circ} \mathrm{C}$ and then treated with $2 \%$ uranyl acetate for $2 \mathrm{~h}$. The material was dehydrated in an ascending series of ethanols, and then in a two ethanol-acetone mixtures. The first consisted of $90 \%$ ethanol and $90 \%$ acetone $(1: 1)$ and the second $90 \%$ ethanol and $96 \%$ acetone (1:1). Dehydration in $96 \%$ acetone, pure acetone and in $99 \%$ propylene oxide was followed by embedding in Epon 812. Roots were sectioned with diamond knives using an LKB Ultratome 3. Ultrathin sections exhibiting a pale gold interference (approximately 60-70 nm thick) were stained with uranyl acetate and lead citrate (Reynolds 1963) and examined with a JOEL JEM 7A transmission electron microscope at an accelerating voltage of $80 \mathrm{keV}$.

\section{RESULTS}

\section{External morphology}

Scots pine seedlings on agar medium produced a root system with a primary root, numerous elongated first-order laterals and 

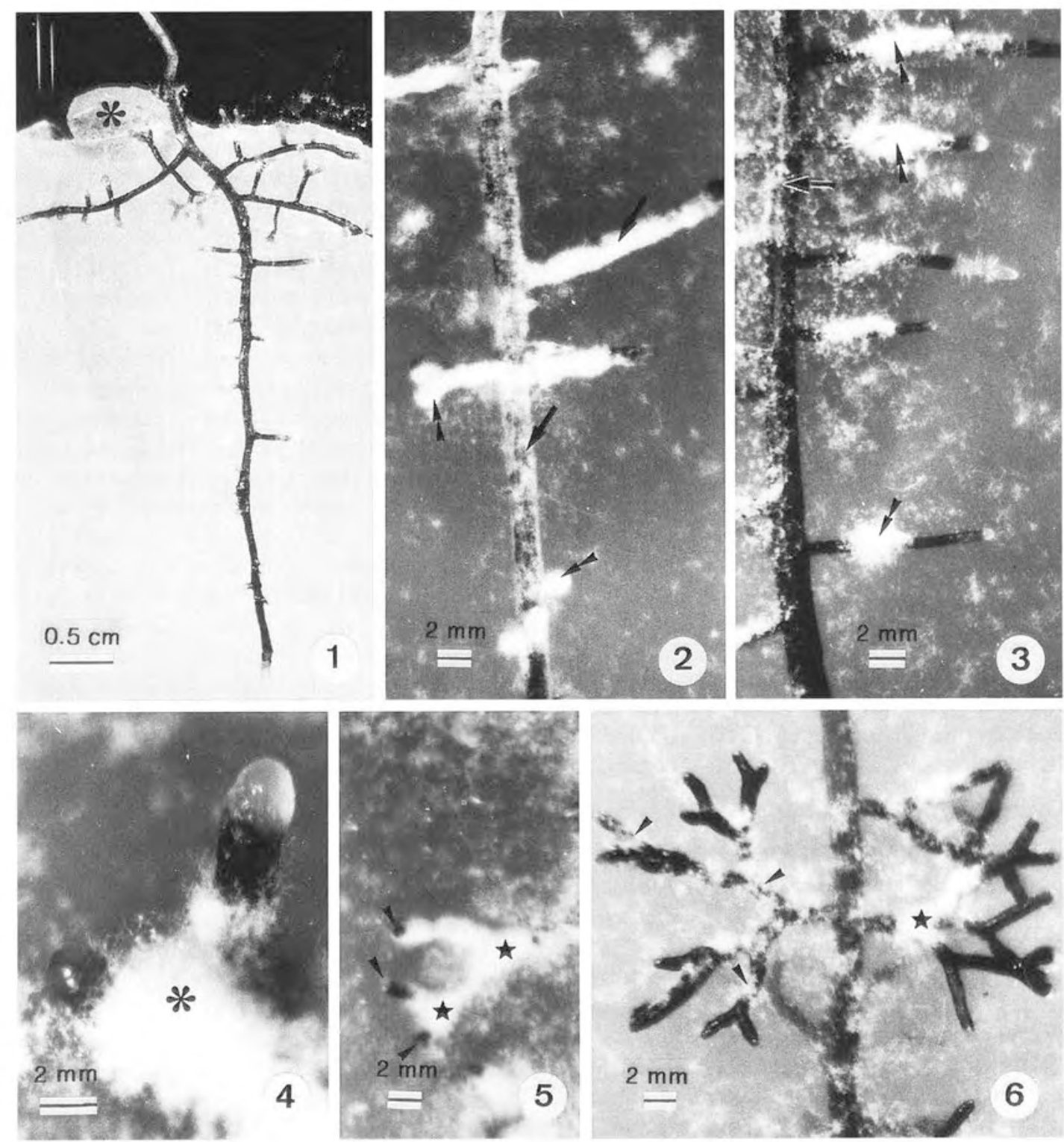

Figs 1-8. External morphology of root systems of Pinus sylvestris seedlings inoculated with Heterobasidion annosum.

Fig. 1. Root system of a six-week-old seedling in a test tube showing the distribution of roots at various stages of development and a plug of mycelium $(*)$. Two weeks after inoculation.

Fig. 2. A portion of the root system of a dying very susceptible seedling. Primary root and laterals enveloped by a thick mycelium (arrows) and root apices of young lateral roots (arrowheads) covered along their entire length with a conspicuous mantle. Three weeks after inoculation.

Fig. 3. A portion of the primary root and first-order laterals of a moderately susceptible seedling. A loose weft of hyphae around the primary root (arrows) and a thicker mycelium (arrowheads) developed at a distance proximal to root apices of elongated lateral roots. One month after inoculation. Fig. 4. Second-order lateral roots of a moderately susceptible seedling. A thick mycelium (*) developed in subapical regions and a scarce hyphal proliferation on the root apices is seen. Three months after inoculation.

Fig. 5. Late stage of colonization of roots of a dying moderately susceptible seedling. Dichotomously branched lateral roots are covered with extremely thick and compact mycelium (*). The mycelium is absent on root apices of second-order laterals and third-order lateral roots (arrowheads). Six months after inoculation.

Fig. 6. A portion of the root system of a resistant seedling showing root clusters of typical pinnate pattern enveloped by a loose weft of hyphae (arrows). A thicker mycelium around subapical region of second-order laterals $(*)$ developed before their branching-off is present. Nine months after inoculation.

second-order lateral roots within 1-2 months. Introduced into the test tube close to the seedling, the fungus developed a mycelium which covered root surfaces (Fig. 1).

Among seedlings dying during the first or second week after inoculation, the majority belonged to a group inoculated with the more aggressive strains. In this group of seedlings the mycelium was formed often only around the root collar, whereas the primary roots and proximal parts of first-order laterals were free from hyphae or were sporadically covered by very sparse mycelium. Roots of seedlings dying at the end of the first month were enveloped by a thick mycelium (Fig. 2). In moderately susceptible seedlings, apart from apical and subapical 
regions, all root surfaces were covered by the hyphae (Fig. 3). During growth stagnation, proximal parts of short roots were enveloped by an especially thick hyphal mat, whereas the hyphae located on root caps formed a loose weft (Figs 4 and 5). In the group of resistant seedlings, hyphal proliferation resulted in a loose weft over the root surfaces. Multiple branching of the lateral roots forming dense clusters was observed in the period of 4-8 months after inoculation (Fig. 6).

\section{Light and transmission electron microscopy of noninoculated roots}

Since regions proximal to the root apices, which correspond with area between the zone of root elongation and the zone of cortical lysis, were covered by a particularly thick mycelium, they were studied in detail.

The vacuolar material displayed blue-green colouration after toluidine blue staining (Fig. 7). Moreover, the hand-cut sections were also „stained" with ferric chloride (not shown). In roots prepared for TEM the material was osmiophilic and most probably phenolic in nature. Contrary to cells of the outer cortex of primary roots (Fig. 8), the cortical cells of first-order lateral roots and second-order laterals accumulated more phenolic materials (Fig. 9) In short roots, the accumulation of phenolic materials coincided with lignification and suberization of walls of root cap cells and suberization of endodermis. These processes led to formation of a metacutis, a typical structure of dormant roots (Fig. 10).

\section{Light and transmission electron microscopy of infected roots}

Infected roots of very susceptible seedlings: In seedlings showing distinct disease symptoms within a few days after inoculation with the more aggressive strains, the entrance of the fungus occurred at the level of the root collar at a point adjacent to the inoculum (Fig. 11). This caused a quick decay of all root tissues in a 1-2-week period (Fig. 12). Compared to control seedlings (Fig. 13), the morphology of superficial cortical cells suggests that cell folding is probably a consequence of natural cell collapse and autolysis, and a liberation of extracellular enzymes by the fungus in the rhizoplane (Fig. 14). In roots of seedlings that had survived till the end of the first month, the fungus was localized in the outer cortex just after inoculation, while 2-4 weeks later the mycelium was also found in the stele. Contrary to parenchyma cells and phloem elements, the tracheids were only slighty decayed (Fig. 15). One month after inoculation the cortical cells were totally disintegrated (Fig. 16).

In general, quick colonization of all the root tissues contrasting with minor damage to structural frame-work of the cortex, slight lignification and sporadic formation of papillae were the common features of the seedlings dying shortly after inoculation with the more aggressive strains of the fungus. In many instances, severe degradation of cortical parenchyma cells and wall breakage characterized seedlings surviving till the end of the first month after inoculation with the less aggressive strain.

Infected roots of moderately susceptible seedlings: In most cases the entrance of the fungus into roots started by means of pushing the hyphae between loosely attached cells of the outer cortex. At the early stage of infection the hyphae grew mostly parallel to the long root axis and were distributed between and inside the cells of the outer cortex (Fig. 17). Roots of the seedlings contained more osmiophilic deposits at very early stage of infection. Frequently, their walls were dark-stained. Observations of infected lateral roots sectioned for LM suggest that, both a blue-green colouration of walls after staining with toluidine blue $\mathrm{O}$ and the dark-stained incrustation of cell walls in roots prepared for TEM are related to increased concentration of phenolics and lignins. In lateral roots of seedlings inoculated with less aggressive strain and studied in TEM, numerous wall appositions were found in cortical cells (Fig. 18). The lack of papillae in root areas ahead of front of the hyphae (Fig. 19) and in the cortex of control plants (Fig. 20), suggests that they are a host reaction to wall perforation. At advanced stage of infection a bleaching of previously dark-stained cell walls coincided with erosion of wall materials (Figs 21 and 22).

The points of direct entering root by hyphae occurred at random and were only occasionally observed. During the initial contact of the fungus with root, a material partially contiguous with an electron-transparent substance and resembling mucilage was observed between the hypha and the root surface (Fig. 23). The hypha adhering to the host surface tapered off and directly entered the host cell. (Fig. 24). When host cell walls were thickened in response to penetration, wall degradation was seen in the form of wide-spread blurred zones in front of the hyphae (Fig. 25). In cortex, the hyphae passed from one cell to another by direct perforation of cell walls. As a result of wall perforation a small hole was formed. Its diameter was variable, from less than $0.5 \mu \mathrm{m}$ to $1 \mu \mathrm{m}$ or more (Fig. 26). During colonization of the cortex, degradation of phenolic deposits became apparent. Initially, they lost their homogeneous texture and assumed granular appearance (Figs 25 and 26). Hyphae located inside degraded cortical cells, still abundant in phenolic materials, showed structure indicative of high metabolic activity (Fig. 27). In areas of advanced infections, the phenolic materials in the form of small dark particles were dispersed in electron-transparent areas (Fig. 28), and finally disappeared.

Infected roots of resistant seedlings: Although roots of control seedlings all the studied half-sib families did not vary in structure, and the amount of phenolic materials was correlated with developmental stage of root (Fig. 29), the unifected root regions of the inoculated resistant seedlings varied substantially in the amount of these materials as compared with similar parts of roots of the other seedlings. In brown parts of the roots, which anatomically correspond with the zone of white tissue of control roots, all cortical cells located at a distance from mycelium displayed deep green colour after staining with toluidine blue $\mathrm{O}$ (Fig. 30). In the proximity of the infected area, the cells became necrotic as they were colonized by the hyphae (Fig. 31). In root regions, which were colonized by external mycelium for a long time there was a total absence of fungal structures in the stele tissue (Fig. 32). However, a few hyphae were always found in the cortex (Fig. 33). Not frequently the penetrating hyphae were confronted by papillae (Fig. 34). The walls of dead cortical cells of short roots were thickened and impregnated with darkstained material (Fig. 35). In the cells particularly abundant in osmiophilic material, strongly vacuolated or dark-stained hyphae were observed (Fig. 36). The phenolic deposits surrounding such necrotic hyphae were, however, not metabolized, judging by their appearance.

\section{Colonization of apical region of roots of pine seedlings}

In peripheral regions of root apices of lateral roots, the hyphae separated contiguous cells. In the centres of the root caps, the intercellular hyphae were located in points of cell junction. Here the hyphae split adjacent cells by pushing themeselves between the cell walls. Apart from the breakdown of compounds middle 

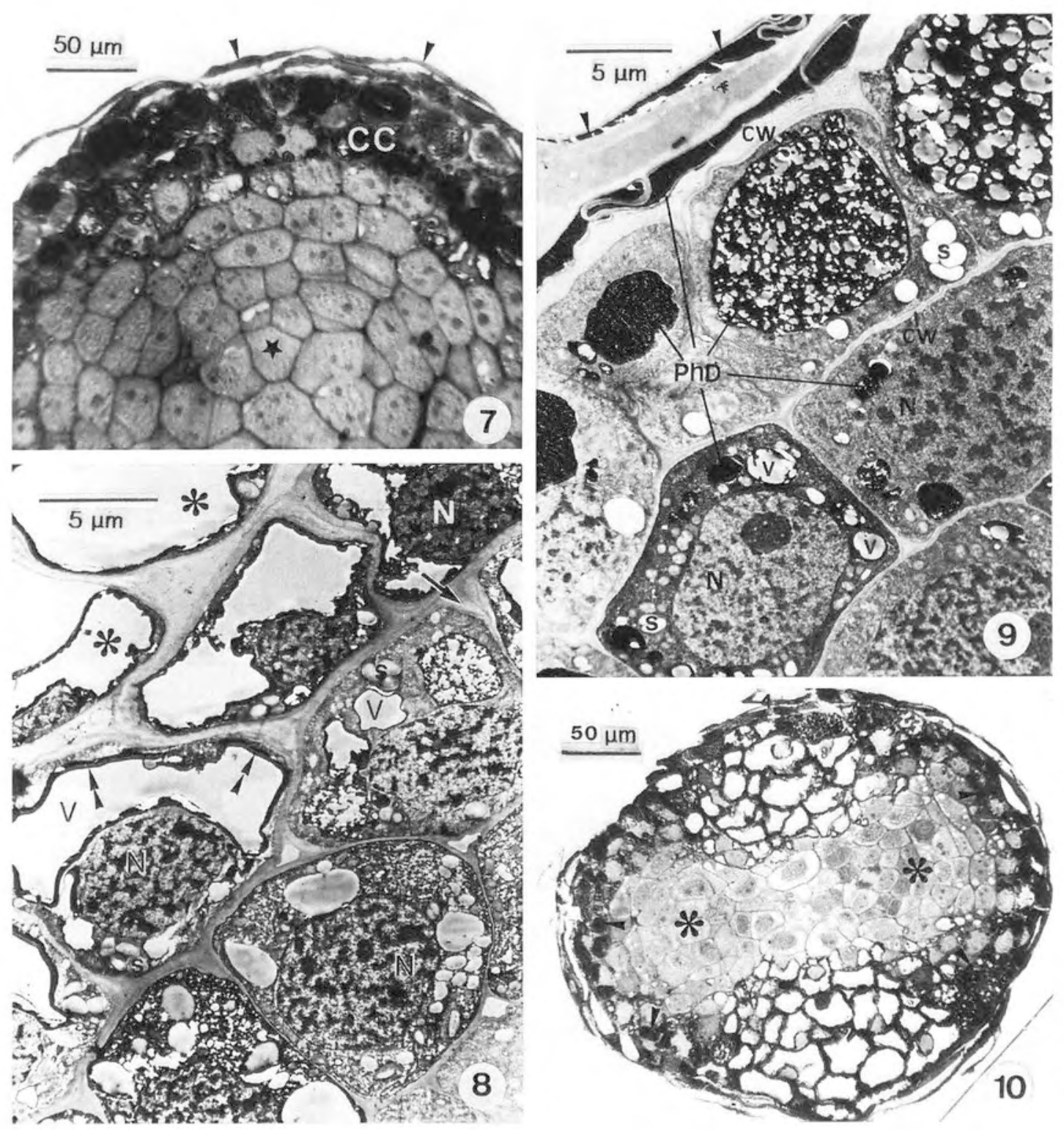

Figs 7-10. Light and transmission electron micrographs of roots at various developmental stages of noninoculated seedlings of Pinus sylvestris. Fig. 7. LM. Transverse section of a long lateral root in an area proximal to the zone of root elongation showing differentiated cortical cells (CC) abundant in dark-stained material and undifferentiated and light-stained cells of central column (*). Moribund cells (arrowheads) forming the outer layers of cortex have started to slough. (arrowheads). Toluidine blue O.

Fig. 8. TEM. Transverse section of a primary root showing a part of the outer cortex composed of strongly vacuolated moribund cells $(*)$ and less vacuolated cells of the inner cortex. Prominent nuclei (N), amyloplasts (S), osmiophilic material (double arrowheads) lining tonoplasts of large vacuoles (V), thick tangential cell walls (arrows) are seen. The outer cortical cells show secondary wall thickenings (arrowheads) mainly at cell corner.

Fig. 9. TEM. Transverse section of a short lateral root showing moribund and folded outer cortical cells (arrowheads) and more deeply located cells containing osmiophilic deposits $(\mathrm{PhD})$ and large starch grains $(\mathrm{S})$. The cells situated below contain prominent nuclei $(\mathrm{N})$ and small vacuoles $(\mathrm{V})$. Note thicker tangential cell walls (CW).

Fig. 10. LM. Transverse section of a short root. The light colour of meristem (*) contrasts with dark colour of outer collar of melanized cells (arrowheads) forming metacutis. Toluidine blue O.

lamella $(\mathrm{CML})$, the fungus exerted a physical pressure on the cells adhered to the hyphae, judging by a tendency of host cell walls to bulge towards the cell lumina (Fig. 37). The hyphae were enclosed in sheaths which tightly filled the spaces resulting from digestion of CML (Fig. 38). In apical regions, the walls of the root cap cells were totally degraded. Frequently, only remnants of protoplasts and liberated vacuoles were visible. Only sporadicaly necrotic hyphae lying close to the ruptured vacuoles were observed (Fig. 39). Examination of numerous living long and short roots, both the resistant and the moderately susceptible seedlings failed to reveal any signs of entering the meristems. This indicates that in the area of melanized cortical cells and root cap cells which form metacutis the fungal growth was hampered or terminated. Moreover, the observations of lateral root initiation provided no evidence of hyphal penetration into meristems of the root primordia (Fig. 40). 

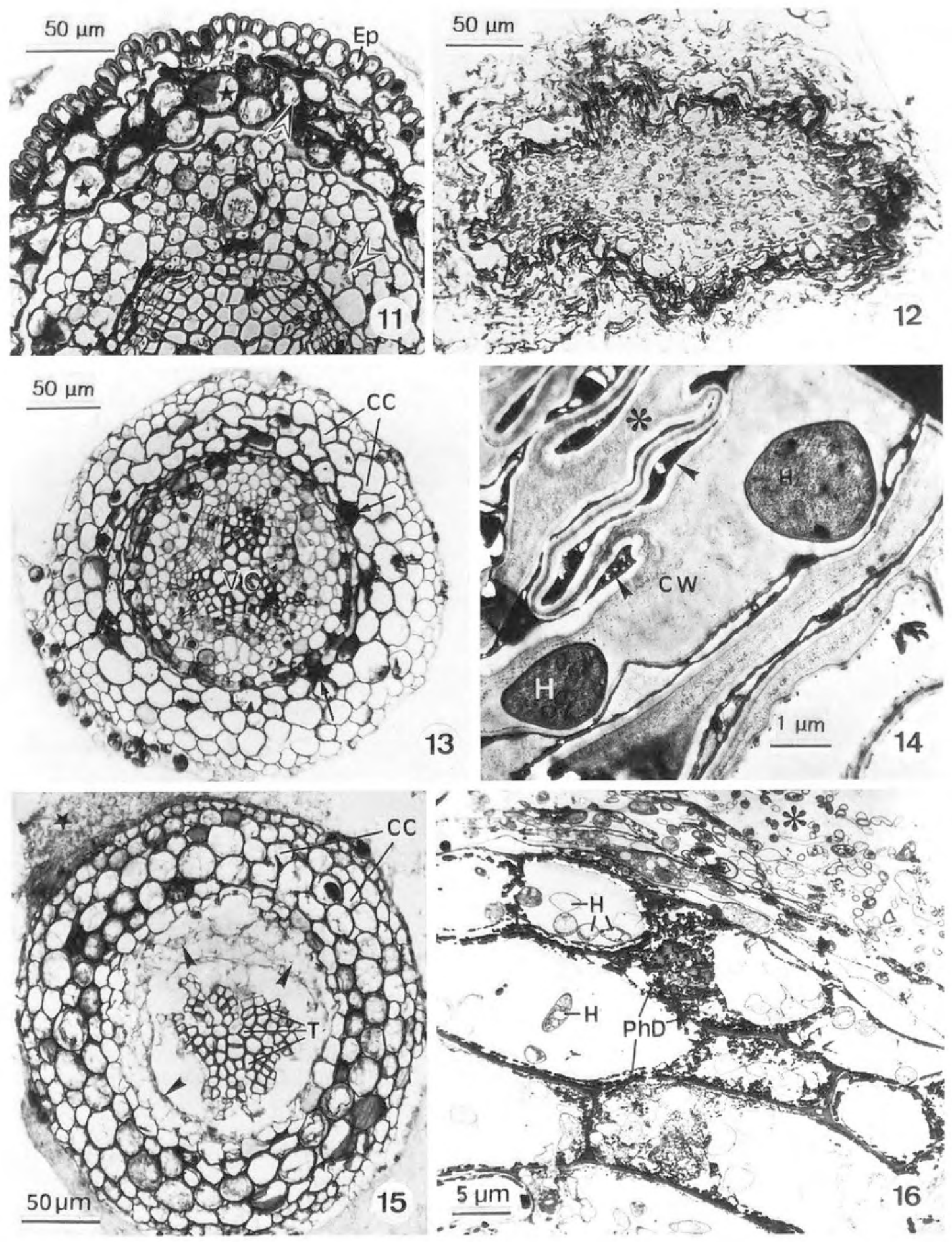

Figs 11-16. Early and late stages of root infection of very susceptible seedlings of Pinus sylvestris.

Fig. 11. LM. Transverse section taken in stem, at point adjacent to plug of mycelium. Colonization of all tissues located under the root collar by hyphae (arrows) is evident. Epidermis (Ep), hypertrophied outer cells of the primary cortex (*) showing thickened walls and tracheids (T) are seen. Two weeks after inoculation. Conant's quadruple stain.

Fig. 12. LM. Transverse section of a primary root of a dead seedling. All tissues of the decayed root are totally disorganized by the fungus. Two weeks after inoculation. Toluidine blue $\mathrm{O}$.

Fig. 13. LM. Transverse section of a primary root of noninoculated control seedling showing multilayered cortex composed of strongly vacuolated cells (CC) and vascular cylinder (VC). A greater amount of dark-stained material (arrows) in cells of the inner cortex are seen. Conant's quadruple stain. Fig. 14. TEM. Periphery of the outer cortex of a primary root. Moribund and sloughing-off cortical cells with folded walls (*), and two hyphae (H) located inside eroded cell wall $(\mathrm{CW})$ are present. Note small amount of osmiophilic material (arrowheads). Three weeks after inoculation.

Fig. 15. LM. Transverse section of a primary root similar to that shown in Fig. 13, showing outer mycelium (*), cortical cells (CC) and the stele heavily colonized by the fungus. Deteriorated and collapsed stelar parenchyma (arrowheads) and slightly destroyed tracheids ( $\mathrm{T}$ ) are seen. One month after inoculation. Conant's quadruple stain.

Fig. 16. TEM. A part of the outer cortex of a long lateral root of the dead seedling showing numerous intracellular hyphae $(\mathrm{H})$ and the others forming external mycelium $(*)$. Note heavy degradation of host cells and low amount and a destructed form of osmiophilic deposits. One month after inoculation. 


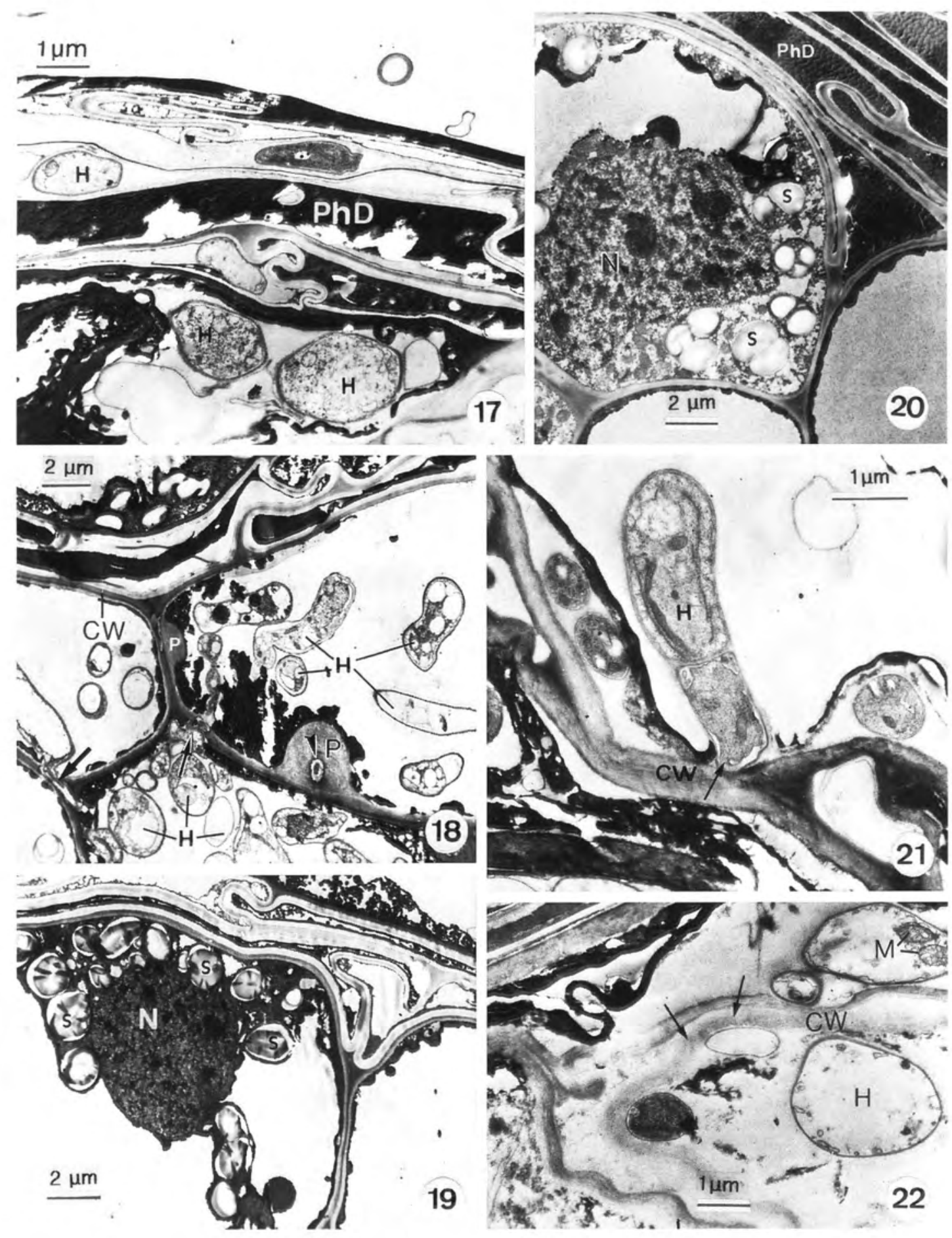

Figs 17-22. Transmission electon micrographs of roots of moderately susceptible $P$. sylvestris seedlings inoculated with $H$. annosum and noninoculated roots of control seedlings.

Fig. 17. Cross section of a first-order lateral root. Vacuolated hyphae $(\mathrm{H})$ are located between and inside outer cortical cells. Abundance of osmiophilic material $(\mathrm{PhD})$ is evident. Six weeks after inoculation.

Fig. 18. Part of the outer cortex of a long lateral root showing numerous hyphae (H), dark stained cell walls (CW), points of the wall perforation (arrows) and papillae (P). Note a small bore hole inside the papilla (arrowhead). Three months after inoculation.

Fig. 19. Cross section of the root shown in Fig. 18, in region adjacent to infected cortex. Dark-stained cell walls, amyloplasts (S) adhered to degenerating nucleus $(\mathrm{N})$ and the lack of papillae are evident. Three months after inoculation.

Fig. 20. Periphery of a long lateral root similar to that shown in Fig. 17 of a three-month-old control seedling. Folded outer cortical cells filled with osmiophilic material $(\mathrm{PhD})$, amyloplasts containing big starch grains $(\mathrm{S})$ are concentrated near the nucleus $(\mathrm{N})$. Primary cell walls $(\mathrm{CW})$ without secondary thickenings are seen.

Fig. 21. Intracellular hypha $(\mathrm{H})$ inside cortical cell of a long lateral root at advanced stage of infection. Arrow indicates narrowed peg of the hypha adjacent to eroded and bleached cell wall $\mathrm{CW}$ ). Four months after inoculation.

Fig. 22. Part of the outer cortex at late stage of host tissue disintegration showing strongly vacuolated hyphae (H) located in vicinity of eroded and stratified cell walls (CW). Note swollen mitochondria (M) inside one of the hyphae. Four months after inoculation. 

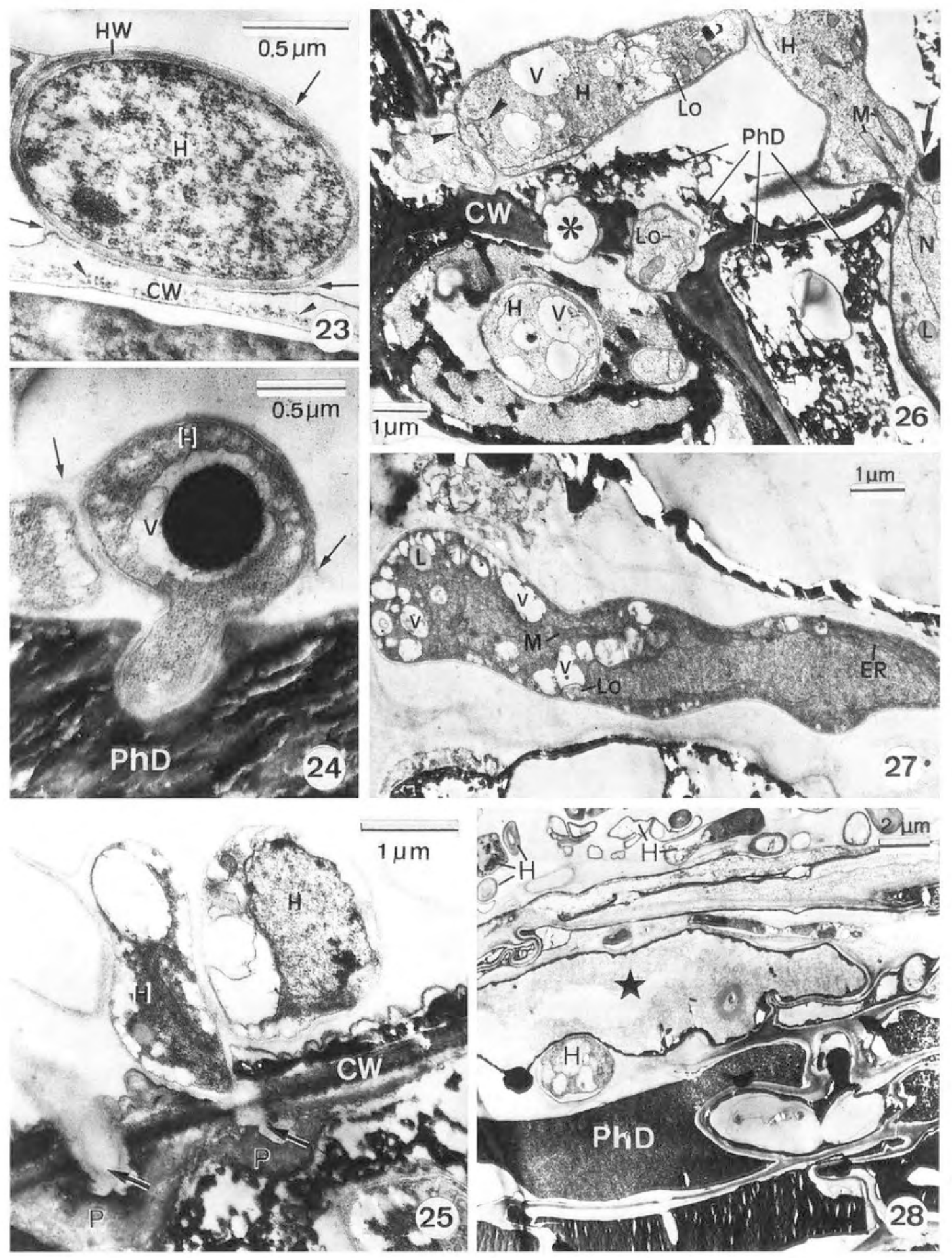

Figs 23-28. Transmission electron micrographs of roots of moderately susceptible $P$. sylvestris seedlings inoculated with $H$. annosum.

Fig. 23. A hypha $(\mathrm{H})$ adhered to the surface of a short root. Scattered dark particles (arrowheads) in resembling mucilage an electron-transparent substance which cover degraded cell wall (CW). Note stratified hyphal wall (HW) and hyphal sheath (arrows) enveloping the hypha and separating host and the fungal structure shortly before penetration. Three months after inoculation.

Fig. 24. A hypha $(\mathrm{H})$ entering a short root via osmiophilic deposit $(\mathrm{PhD})$ of outer cortical cell. Dark-stained globular body situated inside fungal vacuole (V) and sheath material (arrows) left behind the penetrating hypha. Three months after inoculation.

Fig. 25. Penetration of host cell by hyphae (H) confronted by papilla-like thickenings (P). Light-staining lytic areas (arrows) formed at a distance to the penetrating hyphae are present. Note a clear demarcation between dark-stained cell wall $(\mathrm{CW})$ and the papillae. Three months after inoculation. Fig. 26. Parts of four adjacent cortical cells of a short root. Hyphae (H) containing vacuoles (V), nuclei (N), mitochondria (M) and a lomasome-like structure (Lo). Bore hole (*), dark stained cell walls (CW), granular and destructed osmiophilic deposits (PhD) are present. Note constriction of hypha (arrow) passing the host cell wall and dolipore septum with parenthosomes (arrowheads). Four months after inoculation.

Fig. 27. A hypha in the root cortex at late stage of tissue disintegration showing numerous vesicles (Ve) located in vicinity of fungal wall, mitochondria (M), lipid body (L), a lomasome-like structure (Lo) and frequent profiles of endoplasmic reticulum (ER). Four months after inoculation. Fig. 28. Transverse section of a short lateral root showing numerous hyphae of external mycelium (H). Note an electron-transparent area of the outer cortex (*) degraded and colonized by hyphae $(\mathrm{H})$ and electron-opaque $(\mathrm{PhD})$ uncolonized more deeply located cortical cells. Four months after inoculation. 

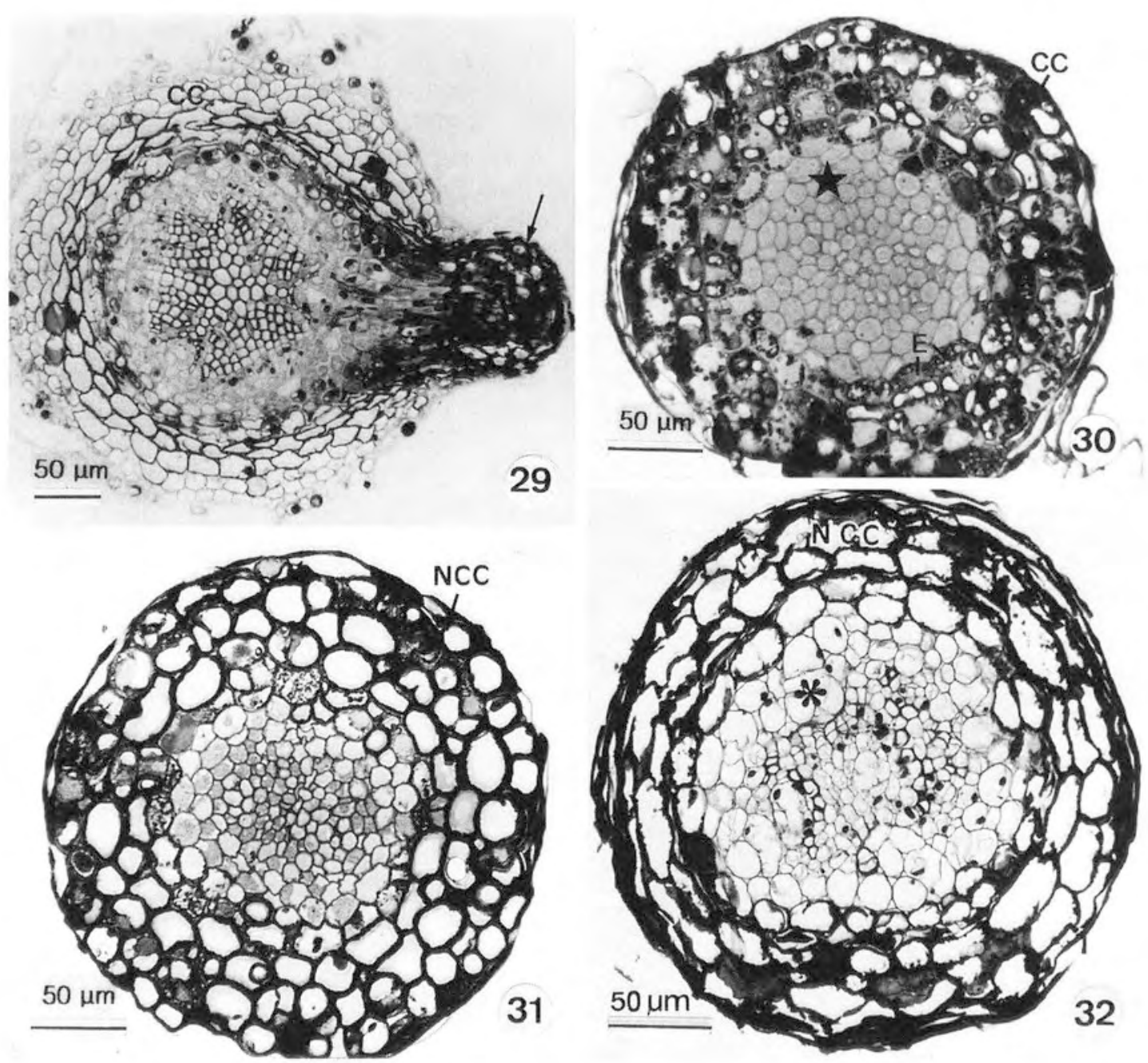

Figs 29-32. Bright field photomicrographs of roots of non-inoculated and inoculated resistant seedlings of $P$. sylvestris.

Fig. 29. Cross section of a primary root showing an emerged lateral root of uninoculated seven-month-old seedling representing progeny of a resistant maternal tree. Note abundance of dark-stained material in cells of dormant short lateral (arrow) and small amount of the material in vacuolated cortical cells (CC) of the primary root. Conant's quadruple stain.

Fig. 30. Cross section of a long lateral root in subapical region at a distance to mycelium. Differentiated cortical cells (CC), endodermis (E) and undifferentiated cells of the stele $(*)$ are seen. Vacuolated and abundant in phenolic material cortical cells contrast with light-stained contents of the stelar cells. Eight months after inoculation. Toluidine blue O.

Fig. 31. Cross section of the root shown in Fig. 30 in area adjacent to infected cortex showing necrotic cortical cells (NCC). Eight months after inoculation. Toluidine blue $\mathrm{O}$.

Fig. 32. Cross section of an older long lateral root in area of infected cortex showing necrotic cells (NCC). Note lack of invasion of the stele (*) by the fungus. Ten months after inoculation. Conant's quadruple stain.

\section{DISCUSSION}

The results provide no evidence for qualitative differences in resistance between the studied progenies, however, they confirmed variation in host responses to infection among all the studied half-sib families. Continuous variation in host resistance among each of the studied progenies strongly suggests polygenically controlled host resistance and aggressiveness of the fungus in the sense of Van der Plank (1968). The differences in host responses to infection were especially marked in two classes of seedlings, which correspond with two extremes of the continuum: very susceptible (1) and resistant (3). The seedlings from the first group were killed by the more aggressive strains within one or two weeks, and their dead roots served as a nutri- ent for saprobic growth or they were able to survive till the end of the first month after inoculation without displaying responses strong enough to limit pathogen growth. The resistant seedlings showed distinct cell necrosis, which after inoculation with the more aggressive strains spread up to endodermis and caused transient or constant localization of the fungus to the cortex. The less aggressive strain usually colonized root tissues more slowly, although it was able to cause the death of seedlings in a 12-month period. In the most heterogeneous group of moderately susceptible seedlings the differences in the aggressiveness of the fungus were the least pronounced.

In contrast to artificial infections of standing trees, and other infection experiments performed in nonsterile conditions, the final outcome of host-pathogen interactions in the study was 
largely dependent on host and pathogen genotypes. The infected roots varied in age, structure and amounts of osmiophilic material and starch. In roots of conifers these features correlate (Harley and Smith 1983). Starch, as a raw material for synthesis of phenolics and resinous compounds contributes to host resistance in stressed tissues (Swedjemark and Stenlid 1996). The differences in the spread of infection in roots of dominant and suppressed Scots pine trees have been found by Gibbs (1968). It is of interest that in the presented study, the group of resistant seedlings was composed of more vigorous individuals, which produced numerous multiple dichotomously branched short roots. The importance of maximum production of fine roots in order to reach a high moisture quotient necessary for resistance to $H$. annosum was demonstrated by Lindberg and Johansson (1992).

Osmium tetroxide reacts with polyphenols, tannins and resins to give black products (Feder and O'Brien 1968). Ability of these compounds to restrict growth of $H$. annosum was studied in detail (reviewed in Asiegbu et al., 1998). In the study the amount of dark-stained materials in outer cortical cells of control seedlings was dependent on cell senescence. This is in line with the findings of Kottke et al. (1986). In the cortex of inoculated pine seedlings it was additionally related to infection. This was best manifested in those parts of roots which were located in front of mycelium. The increased concentration of phenolics that stain blue-green with toluidine blue and are osmiophilic in plant material prepared for TEM has been observed in other host-pathogen interactions (Bonello et al., 1991) and host-mycorrhizal fungus associations (Ling-Lee et al., 1977; Massicotte et al., 1987; Kottke and Oberwinkler 1988, among others). Moreover, the abundance of phenolic material observed at the early stage of infection may indicate an elevated processes of lignification (O'Brien et al., 1964; O'Brien and McCully 1981).

The results of the study show that the defence responses of $P$. sylvestris seedlings are similar to those induced by $H$. annosum in nonsuberized and suberized roots of P. abies (Asiegbu et al., 1993, 1994, 1995; Heneen et al., 1994a, 1994b). An increase in phenolic material in cortical cells ahead of the fungus and modifications of host cell walls were the common features of infected roots of the studied moderately susceptible and resistant seedlings. Since they correspond to higher root resistance, may be taken as evidence of the defence reactions. These suggest an ability of $H$. annosum to elicit a hypersensitive reaction (HR).

A capacity of the fungus to elicit HR in ray parenchyma cells of pine and spruce trees far in advance of infection was suggested by Shain (1979), but in contrast to biotrophs, it is able to tolerate this host response (Johansson and Stenlid 1985; Lindberg and Johansson 1991). Since papillae are recognized as an unspecific host reaction or a defence reaction of living host protoplasts to penetration caused by obligatory pathogens (Bracker and Littlefield 1973) or nonpathogenic fungi (Ride and Pearce 1979), their role in plant defence against necrotrophic fungus is doubtful due to a strong destruction of host protoplasts in front of the fungus. In spite of numerous papillae observed occasionally in roots of moderately susceptible seedlings inoculated with less aggressive strain, the cortical cells were inevitably abundant in hyphae in advanced stage of infection. This suggests that although the papillae slowed down wall perforation, they did not limit this process significantly. Higher frequency of papillae found in several roots inoculated with this strain may be related to a long reaction time of less injured cells.
In spite of in vitro conditions, the study provided strong structural evidence for the occurrence of processes similar to those observed in excised woody roots of $P$. abies (Johansson and Stenlid 1985; Stenlid and Johansson 1987), which are in accordance with the results on advanced infections of standing trees (Shain 1967, 1971, 1979). In pine seedlings the properties of the root area ahead of the hyphae are similar to those of the transition zone. This zone, due to increased level of protective materials and various autolytic deleterious products of dying cells. such as lytic enzymes and phytoalexins, function as mechanical and chemical barriers. Many compounds, including free radicals or phenols oxidized by laccase, such as quinones, are known to exert a strong effect on activity of extracellular enzymes and fungal growth (Johansson and Stenlid 1985; Asiegbu et al.. 1998). The dead or immobilized hyphae, entrapped in osmiophilic materials of the resistant seedlings, confirm such a supposition. This same phenomenon has been described for spruce seedlings by Heneen et al. (1994a). On the basis of similar findings, inability of the fungus to enter the sapwood through the phlobaphene cork was suggested by Peek et al. (1972). Sequential changes in microtexture of phenolic deposits and their disappearance in areas of advanced infections obviously represent structural evidence of chemical transformation of the accumulated protective materials. At advanced stage of infection, abundant in hyphae the electron-transparent area of the outer cortex may coincide with the zone of reduced toxicity described by Johansson and Stenlid (1985).

The importance of endodermis in the resistance of young roots of $P$. sylvestris to $H$. annosum should not be overestimated. The restriction of the fungus to the outer cortex of resistant seedlings was achieved mostly through strong hypersensitive reactions, whereas the hyphae usually colonized vascular tissues of other seedlings. In studies by Asiegbu et al. (1993, 1994 , 1995 ) the fungus entered the stele of primary roots via endodermis. Despite the high susceptibility of the meristematic tissue, no evidence was provided for invading the stele via meristem. In the presented study the destruction of meristems was observed only in dead or dying seedlings after invasion of the stele by the fungus in upper region of root systems. This can be explained by inability of the fungus to achieve an infection potential high enough to enter the meristem via metacutis. The differences between the presented results concerning the ability to colonize and cause further decay of various root tissues and the others described by Asiegbu et al. (1993, 1994), Heneen et al. (1994a) may be partly due to different developmental stages of roots, inoculation procedures, aggressiveness of the fungi and host susceptibility. It is obvious that these variables influence the spread of the pathogen in roots.

The wall erosion and separation of root cap cells due to breakdown of CML may be related to a high pectinolytic activity of P strains of the fungus (Johansson 1988; Karlsson and Stenlid 1991; Karjalainen 1994). Availability of pectins in the primary cortex and root apices of long roots may create an environment which does not favour utilization of cellulose as a source of energy for the fungus. According to Horton and Keen (1966), suppression of cellulase activity is dependent on the ability of a host-plant to keep a fungus supplied with easily available carbohydrates, and the ability of the fungus to metabolize them. Since lignin and cellulose constitute only a temporary protection for the fungus until their corresponding hydrolyzing and oxidizing enzymes appear (Johansson and Stenlid 1985), the fungus can meanwhile utilize a variety of carbon sources. 


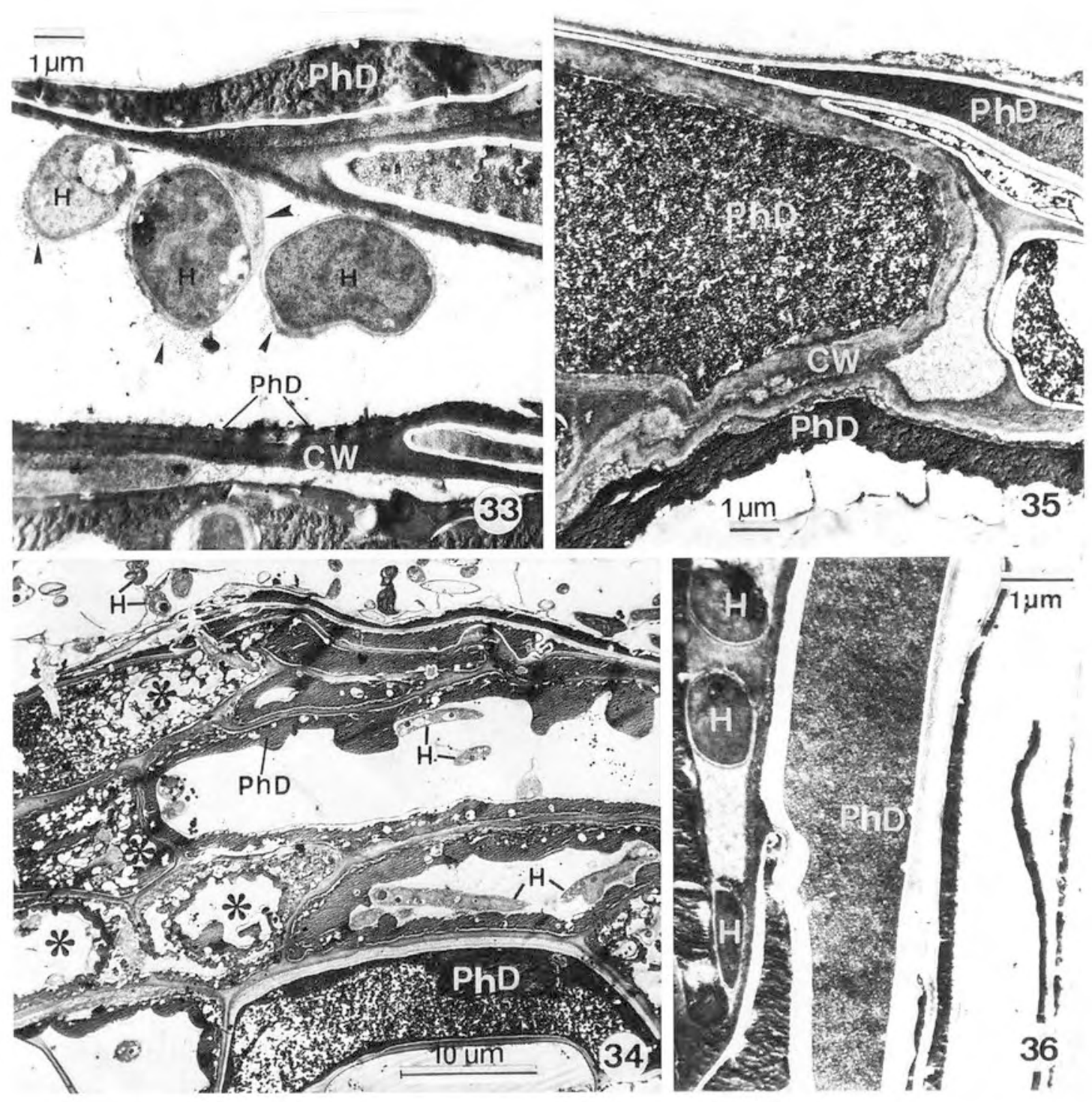

Figs 33-36. Transmission electron micrographs of roots of resistant seedlings of $P$. sylvestris inoculated with H. annosum.

Fig. 33. Cross section of a long lateral root showing hyphae $(H)$ situated in outer cortical cells. Hyphal sheaths (arrowheads), dark-stained host cell walls $(\mathrm{CW})$. Note thick hyphal wall and darkly stained protoplast of a necrotic hypha (NH) located inside osmiophilic deposit (PhD). Ten months after inoculation.

Fig. 34. Cross section of a long lateral root colonized by hyphae (H). Osmiophilic deposits which show unchanged appearance (PhD) in less affected cells and their destructed form in cells heavily colonized by the fungus $(*)$. Nine months after inoculation.

Fig. 35. Outer cortical cells of uninfected short root showing amorphous osmiophilic deposits (PhD) and thick and dark stained cell walls (CW). Ten months after inoculation.

Fig. 36. Part of the outer cortex of a short root showing three dark-stained and most probably immobilized hyphae (H). Ten months after inoculation.

Assuming that especially pectins and hemicelluloses are decomposed, the observed stratification of primary walls at an advanced stage of their degradation may suggest an exposure of cellulose microfibrils. Because of a high percentage of pectins and pectates in both primary walls and middle lamellae, the parenchyma cells of pine seedlings obviously served as the main source of carbon for the fungus. Although a high pectinolytic activity of $H$. annosum at an early stage of infection in ray parenchyma has been confirmed by Johansson and Stenlid (1985), the importance of pectin-degrading enzymes in the spread of infection is not still well recognized. The presented study provides structural evidence for importance of these enzymes in pathogenesis. The roots containing undegraded tracheids and destroyed, collapsed parenchyma cells and phloem elements indicate that in contrast to pectinolytic enzymes, ligno-cellulolytic enzymes are probably less operative.

\section{ACKNOWLEDGEMENTS}

This study was supported by the Institute of Dendrology, Polish Academy of Sciences. We thank Mrs. Anna Błaszkowiak for providing assistance at the coarse of the research. 

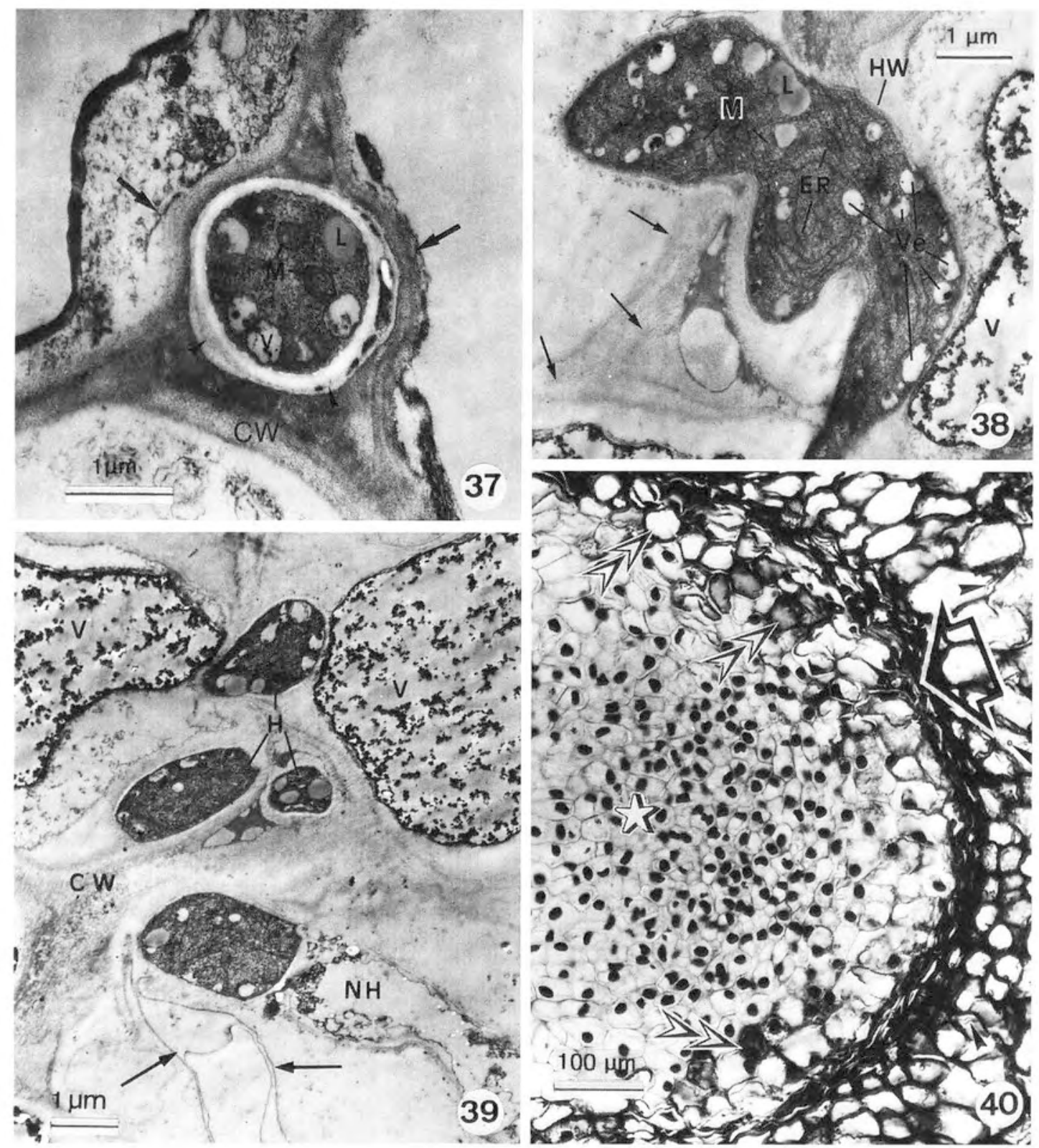

Figs 37-40. Light and transmission electron micrographs of root caps of lateral roots of resistant seedlings of $P$. sylvestris inoculated with H. annosum.

Fig. 37. A hypha $(\mathrm{H})$ situated at point of cell junction in central area of root cap of a long lateral root. Vacuoles (V), mitochondria (M) and lipid body (L). Hyphal sheath (arrowheads) and bulges (arrows) of host cell walls (CW) are seen. Eight months after inoculation.

Fig. 38. A hypha $(\mathrm{H})$ at peripheral area of root cap of a lateral root showing numerous vesicles (Ve), lipid bodies (L), mitochondria (M) and endoplasmic reticulum (ER) running parallel to hyphal wall (HW). Eroded cell wall (CW) showing stratification (arrows) and liberated vacuole (V) containig scattered dark particles are seen. Nine months after inoculation.

Fig. 39. Necrotic and vacuolated hypha $(\mathrm{NH})$ in area of root cap of short root showing remnants of protoplast in association with membraneous structures. Hyphae $(\mathrm{H})$ adjacent to dacayed cell wall $(\mathrm{CW})$ and undestroyed vacuoles $(\mathrm{V})$ which appear to be unaffected are seen. Nine months after inoculation.

Fig. 40. Bright field photomicrograph. Cross section of a main root showing a lateral root primordium (*), Several layers of crushed cortical cells (arrow), thick-walled and melanized cells of root cap (double arrowheads) which surround meristem of the root primordium are present. Note hyphae (arrowheads) in the cortex of main root and lack of invasion of the fungus into the meristem. One year after inoculation. Hematoxylin + Stirling's violet. 


\section{LITERATURE CITED}

ASIEGBU F., DANIEL G., JOHANSSON M. 1993. Studies on the infection of Norway spruce roots by Heterobasidion annosum. Can. J. Bot. 71: 1552-1561.

ASIEGBU F.O., DANIEL G., JOHANSSON M. 1994. Defence related reactions of seedling root of Norway spruce to infection by Heterobasidion annosum (Fr.) Bref. Physiol. Mol. Plant Pathol. 45: 1-19.

ASIEGBU F.O., DANIEL G. JOHANSSON M. 1995. Infection and disintegration of vascular tissues of nonsuberized roots of spruce by Heterobasidion annosum and use of antibodies for characterizing infection. Mycopathologia, 129: 91-101.

ASIEGBU F.O., JOHANSSON M., WOODWARD S., HÜTTERMAN A. 1998. Biochemistry of the host-parasite interaction. In Heterobasidion annosum. Biology, Ecology, Impact and Control. Edited by S. Woodward, J. Stenlid, R. Karjalainen and A. Hüttermann. University Press, Cambridge pp. 167-193.

BAGIŃSKI S. 1969. Technika mikroskopowa. PWN. Warszawa.

BONELLO P., PEARCE R.B., WATT F., GRIME G.W. 1991. An induced papilla response in primary roots of Scots pine challenged in vitro with Cylindrocarpon destructans. Physiol. Mol. Plant. Pathol. 39: 213-228.

BRACKER C.E., LITTLEFIELD L.J. 1973. Structural concepts of host-pathogen interfaces. In: Fungal Pathogenicity and the Plant's Response. Byrde R.J.W., Cutting C.V. (ed.) Academic Press London. New York. pp. 159-318.

DELATOUR C. 1982. Behaviour of Fomes annosus in the stem of Norway spruce and in the laboratory. In: Resistance to diseases and pests in forest trees. Heybroek H.M., Stephan B.R. von Weissenberg K. (ed.). Wageningen. pp. 268-274.

DIMITRI L. 1994. Host defence and genetical resistance of Norway spruce (Picea abies (L.) Karst. against Heterobasidion annosum (Fr.) Bref. In: Proceedings of the 8th IUFRO Conference on Root and Butt rots, Sweden/Finland, August 9-16, 1993. Johansson M., Stenlid J. (ed.). Uppsala, Sweden. pp. 1-6.

FEDER N., O'BRIEN T.P. 1968. Plant microtechnique; some principles and new methods. Am. J. Bot. 55: 123-142.

GIBBS J.N. 1968. Resin and the resistance of conifers to Fomes annosus. Annals of Botany, 32: 649-665.

HARLEY J.L., SMITH S.E.S. 1983. Mycorrhizal symbiosis. Academic Press, London and New York.

HENEEN W.K., GUSTAFSSON M., KARLSSON G., BRISMAR, K. 1994a. Interactions between Norway spruce (Picea abies) and Heterobasidion annosum. I. Infection of nonsuberized and suberized roots. Can. J. Bot. 72: 872-883.

HENEEN W.K., GUSTAFSSON M., BRISMAR K., KARLSSON G. 1994b. Interactions between Norway spruce (Picea abies) Heterobasidion annosum. II. Infection of woody roots. Can. J. Bot. 72: 884-889.

HORTON J., KEEN N.T. 1966. Sugar repression of endopolygalacturonases and cellulase synthesis during pathogenesis by Pyrenochaeta terrestris as a resistance mechanism in onion root. Phytopathology 56: 908.

JENSEN W.A. 1962. Botanical Histochemistry. Principle and Practice. Freeman and Co. San Francisco and London.

JOHANSEN D.A. 1940). Plant microtechnique. McGraw-Hill, New York.

JOHANSSON M. 1988. Pectic enzyme activity of spruce (S) and pine (P) strains of Heterobasidion annosum (Fr.) Bref. Physiol. Mol. Plant Pathol. 33: 333-349.

JOHANSSON M., UNESTAM T. 1982. The search for resistance to Heterobasidion root rot in Norway spruce-old and new approaches in studies of infection biology. Eur. J. For. Path. 12: 346-357.

JOHANSSON M., STENLID J. 1985. Infection of roots of Norway spruce (Picea abies) by Heterobasidion annosum. 1. Initial reactions in sapwood by wounding and infection. Eur. J. For. Path. 15: $32-45$.
KARLSSON J.O., STENLID, J. 1991. Pectic isozyme profiles of the intersterility groups in Heterobasidion annosum. Mycological Research, 95: 531-536.

KARJALAINEN R. 1994. Towards the molecular analysis of Heterobasidion annosum. In: Proceedings of the 8th IUFRO Conference on Root and Butt Rots. Sweden/Finland. August 9-16, 1993. Johansson M., Stenlid J. (ed). Uppsala, Sweden. pp. 292-3() 2 .

KORHONEN K. 1978. Intersterility groups of Heterobasidion annosum. Comm. Inst. For. Fenn. 94: 1-25.

KOTTKE J., RAPP CH., OBERWINKLER F. 1986. Zur Anatomie gesunder und ,kranker” Feinstwurzeln von Fichten: Meristem und Differenzierungen in Wurzelspitzen und Mykorrhizen. Eur. J. For. Path. 16: 159-171.

KOTTKE J., OBERWINKLER F. 1988. Comparative studies on the mycorrhization of Larix decidua and Picea abies by Suillus grevillei. Trees, 2: 115-128.

LINDBERG M., JOHANSSON M. 1991. Growth of Heterobasidion annosum through bark of Picea abies. Eur. J. For. Path. 21: $377-$ -388 .

LINDBERG M., JOHANSSON M. 1992. Resistance of Picea abies seedlings to infections by Heterohasidion annosum in relation to drought stress. Eur. J. For. Path. 22: 115-124.

LING-LEE M., CHILVERS G.A., ASHFORD A.E. 1977. A histochemical study of phenolic materials in mycorrhizal and uninfected roots of Eucalyptus fastigata Deane and Maiden. New Phytol. 78: 313-328.

MASSICOTTE H.B., PETERSON R.L., ACKERLY C.A., ASHFORD A.E. 1987. Ontogeny of Eucalyptus pilularis - Pisolithus tinctorius ectomycorhizae. II. Transmission electron microscopy. Can. J. Bot. 65: 1927-1939.

O'BRIEN T.P., McCULLY M.E. 1981. The study of plant structure: principles and selected methods. Termarcarphi Pty Ltd., Melbourne. Australia.

O'BRIEN T.P., FEDER N., McCULLY M.E. 1964. Polychromatic staining of plant cell walls by toluidine blue O. Protoplasma, 56: 367-373.

PACHLEWSKA J. 1968. Badania nad syntezą mikoryzową sosny (Pinus sylvestris L.) w czystych kulturach na agarze. Prace IBL 345: 1-76. (in Polish)

PEEK R.D., LIESE W., PARAMESWARAN N. 1972. Infektion und Abbau der Wurzelrinde von Fichte durch Fomes annosus. Eur. J. For. Path. 2: 104-115.

REYNOLDS E.S. 1963. The use of lead citrate at high $\mathrm{pH}$ as an electron-opaque stain in electron microscopy. J. Cell. Biol. 17: 208- 212.

RIDE J.P., PEARCE R.B. 1979. Lignification and papilla formation at sites of attempted penetration of wheat leaves by nonpathogenic fungi. Physiol. Plant Pathol. 15: 79-92.

SHAIN L. 1967. Resistance of sapwood in stems of Loblolly pine to infection by Fomes annosus. Phytopathology, 57: 1()34-1()45.

SHAIN L. 1971. The response of sapwood of Norway spruce to infection by Fomes annosus. Phytopathology, 61: 301-307.

SHAIN L. 1979. Dynamic responses of differentiated sapwood to injury and infection. Phytopathology, 69: 1143-1147.

SHAIN L., HILLIS W.E. 1971. Phenolic extractives in Norway spruce and their effects on Fomes annosus. Phytopathology, 61: 841-845.

STENLID J., JOHANSSON M. 1987. Infection of roots of Norway spruce (Picea abies) by Heterobasidion annosum. II Early changes in phenolic content and toxicity. Eur. J. For. Path. 17: 217-226.

SWEDJEMARK G., STENLID J. 1996. Variation in spread of Heterobasidion annosum in clones of Picea abies grown at different vegetation phases under greenhouse conditions. Scand. J. For. Res. 11: 137-144.

TIPPETT J.T., SHIGO A.L. 1980. Barrier zone anatomy in red pine roots invaded by Heterobasidion annosum. Can. J. For Res. 1(): 224-232 .

TIPPETT J.T., SHIGO A.L. 1981. Barriers to decay in conifer roots. Eur. J. For. Path. 11: 51-59. 
VAN DER PLANK J.E. 1968. Disease Resistance in Plants. Academic Press, New York and London.

WERNER A. 1987. Responses of in vitro grown pine seedlings to infection by four strains of Heterobasidion annosum. Eur. J. For. Path. 17: 93-101.

WERNER A. 1991a. Odporność sosny zwyczajnej na hubẹ korzeni i przebieg choroby siewek sosny zakażonych grzybem Heterobasidion annosum. (Resistance of Scots pine to root rot and the disease of pine seedlings infected by Heterobasidion annosum). D. Sc. thesis, Institute of Dendrology, Polish Academy of Sciences, Kórnik, PWR i L Poznań, pp. 1-168. (in Polish)

WERNER A. 1991 b. Odporność drzew sosny zwyczajnej pierwszej drugiej generacji w ognisku choroby wywołanej przez grzyb Heterobasidion annosum (Fr.) Bref. (Resistance to Heterobasidion annosum of first and second generation Scots pine trees from an old disease center). Arboretum Kórnickie 36: 113-126. (in Polish)

\section{INTERAKCJE POMIĘDZY SIEWKAMI SOSNY ZWYCZAJNEJ (PINUS SYLVESTRIS L.) I SZCZEPAMI TYPU P GRZYBA HETEROBASIDION ANNOSUM (FR.) BREFELD W WARUNKACH IN VITRO}

\section{STRESZCZENIE}

Siewki sosny zwyczajnej (Pinus sylvestris L.), będące potomstwem drzew różniących się stopniem odporności na hubę korzeni w środowisku leśnym, zakażono trzema szczepami grzyba Heterohasidion annosum (Fr.) Bref. w warunkach in vitro. Do badań wybrano szczepy typu P, o wysokiej preferencji w stosunku do sosny, różniące siẹ jednak agresywnością. Standardowa metoda inokulacji oraz warunki in vitro pozwoliły wyeliminować wpływ czynników zewnętrznych modyfikujących genetycznie uwarunkowaną obronność roślin i agresywność patogena. Na korzeniach siewek podatnych grzyb tworzył grubą i zwartą opilśń, natomiast luźny splot strzẹpek otaczał zazwyczaj korzenie siewek o wyższej odporności. Wczesną oznaką nekrotycznych reakcji komórek kory pierwotnej sąsiadujących z grzybnią było gromadzenie siẹ w wakuolach osmofilnego materiału o cechach polifenoli i tanin, grubienie ścian pierwotnych i inkrustowanie ich ligniną. Intensywność i szybkość reakcji o charakterze nadwrażliwościowym pozwalała odróżnić je od naturalnych procesów warunkowanych starzeniem siẹ komórek kortykalnych. Obecność zdegenerowanych strzẹpek w materiale osmofilnym, zdeponowanym w wakuolach komórek kortykalnych u siewek o wyższej odporności, wskazuje na wyższą toksyczność związków fungistatycznych generowanych w nadwrażliwościowo reagujących komórkach. Brak nekrotycznych reakcji oraz niewielka ilość osmofilnego materiału, zgromadzonego w korzeniach siewek podatnych w okresie poprzedzającym kolonizacje komórek przez grzyba, sprzyjały szybkiemu przenikaniu strzępek do tkanek waskularnych i zamieraniu roślin. Zmiany zachodzące w strukturze materiału osmofilnego i jego zanik poprzedzały intensywną kolonizację komórek kortykalnych u siewek o przeciẹtnym stopniu odporności. Poza uszkadzaniem komórek czepka nie zaobserwowano przenikania strzẹpek do merystemów korzeni żywych roślin. Obecność grzybni w tkance merystematycznej stwierdzano u podatnych siewek, u których przenikanie strzępek grzyba do tkanek walca osiowego następowało w górnych czẹściach systemu korzeniowego i było przyczyną ich wczesnego zamierania.

SŁOWA KLUCZOWE: siewki Pinus sylvestris, Heterobasidion annosum, zakażenie korzeni, odporność, mikroskopia świetlna, TEM. 